\title{
Exploratory Study on Malaysia Construction Leadership
}

\author{
Nur Ain Ngah Nasaruddin ${ }^{1, *}$, and Ismail Abdul Rahman ${ }^{1}$ \\ ${ }^{1}$ Department of Building and Construction Engineering, Faculty of Civil and Environmental \\ Engineering, Universiti Tun Hussein Onn Malaysia, 86400 Parit Raja, Johor, Malaysia
}

\begin{abstract}
This paper presents an exploratory study on insight issues of leadership quality in Malaysia construction industry. It was conducted using an open interview session which focussed on three main elements which are challenges faced by construction leaders, leader's role to sustain organization's competitiveness and qualities to be an outstanding construction leader. Even though only four senior construction leaders were selected for this qualitative study, but the selection was properly scrutinised based on their expertise as construction leader. During the interview session, leaders were given ample time to express their opinions on the elements with minimum interference. Information revealed was recorded, analysed and synthesized to deduce findings of the study. It was found that significant challenges faced by construction leaders are ensuring project runs smoothly, managing cash flow and ability to manage large number of worker. For ensuring their organization remains competitive, leaders must be creative and persistence in handling construction project and not merely completing the task. To be outstanding, leaders should possess good leadership attributes as problem solver, communicator and motivator in their organizations. This study forms a basis for further exploration on leadership quality for construction industry.
\end{abstract}

\section{Introduction}

Rapid growth of construction industry in Malaysia leads to the need for an efficient construction project management teams, especially in terms of leadership. Managing construction project with less spirit of leadership can weaken the organization in its ability to deal challenges in construction industry [1]. According to [2], leadership requires influence to complete missions and to give directions for more well-organized and practical organization. Previous researchers had outlined several issues of leadership in the construction industry such as poor communication, lack of experience, lack of planning, wrongful use of power, lack of adaptability with complex circumstance, lack of resources, lack of strategy management, and lack of superior support [3]. A study found that positive leadership contributed almost $76 \%$ to the success of project while negative or poor leadership has contributed to $67 \%$ of projects failure [4]. Thus, the need of quality leadership is undeniable to steer construction project success. With appropriate leadership

*Corresponding author: nurain_ngah@yahoo.com 
among the construction parties will enable to navigate the construction process in a sustainable manner [5]. Quality leaders able to lead project team in an efficient and effective manner to accomplish the organization and project goals. Hence this exploratory study was intended to gain better understanding of issues on leadership quality in Malaysian construction industry.

\section{Methodology}

This exploratory study adopted qualitative approach in gathering information from respondents through open interview sessions where the respondents were minimally guided to focus on the identified issues. Guiding questions were prepared based on the literature which comprises of three main elements which are challenges faced by construction leaders, leaders' role to sustain organization's competitiveness and qualities to be outstanding construction leaders. Selection of respondents is crucial in qualitative approach where they should have sound knowledge and experiences on the subject matter to ensure the reliability and validity of their opinions. This study has identified four construction leaders selected from highest G7 grade of CIBD database with working experience for more than 15 years and holding top managerial position. Construction leaders are considered experts of Malaysia construction industry that can contribute reliable information [6].

Experts were contacted to make appointments and to inform the intentions of the interview session for their preparation. Interview sessions were conducted through new technique known as OREO which means Opinion, Reason, Evidence, And Opinion's suggestion [7]. In this technique, experts were required to give opinions on the issues based on their knowledge and experience. Besides giving opinions, they are required to provide reasons/justifications for their opinion and if possible with evidences. Finally, they are required to give suggestions on their opinions. The interview session was conducted in face to face mode where the given information was recorded manually and also captured electronically. Experts were given ample time to voice their opinions on the given topic and gently guided to avoid deviation from the interview's objectives. Information gathered from the interview was analysed and synthesized to produce quality interview transcriptions which elaborate pertinent points in systematic and logical arrangement. These transcriptions were summarized in deductive manner to establish findings.

\section{Interviews outcomes}

Demography of four experts who participated in this interview are as follows: the first expert has being in the industry for more than 36 years and handled several mega construction projects, the second expert has being in the industry for more than 33 years and also owner of organization, while the third expert having 15 years of working with government mega projects and holding top management position and the final expert having 15 years of working with private mega projects and holding top management position.

\subsection{Challenges faced by construction leaders}

In the first part of the interview session, experts were requested to voice their opinions regarding challenges faced by construction leaders under the current scenario. The first expert responded by stating three primary challenges facing construction leaders today which are to achieve completion of the targeted construction successfully, ensuring all team 
members review and respect the project schedule tightly, and managing team member attitude \& work ethics correctly. To the second expert, the challenges are to ensure construction project runs smoothly without interference from employee problem, salary disputes, damaged machinery \& the uncertainty of building materials prices, and managing cash flow. According to this expert, Malaysia construction industry is facing the shortages of skilled workers and the available foreign workers do not have permit and valid green card to work in Malaysia. Hence, leaders have to address this challenge before entering their workers to work at the construction site. Leaders need to compete for getting workers quickly by giving higher salary to prevent salary disputes among workers. Other important issues are the increases of construction materials prices after project awarded and late payments from the client affecting their cash flow.

According to the third expert, the challenges are to handle the large numbers of worker at one time on the site, handling construction projects in the hectic work area with unstoppable traffic at entry and exit route in the daytime, managing project cash flow with late payment from the client, and ensuring no construction drawing error such as the not accurate of measurement $\&$ design errors that will lead to rework. For the fourth expert, construction leaders are facing challenges to ensure the project runs smoothly with the problems of increased of construction material prices, lack of skilled worker on site, employing foreign workers with higher rate of workers levy fees and others. The outcomes for the challenges faced by construction leaders can be summarised as in Table 1 .

Table 1. Summary of challenges faced by construction leaders.

\begin{tabular}{|c|c|c|c|}
\hline $\begin{array}{c}\text { First } \\
\text { Expert }\end{array}$ & Second Expert & $\begin{array}{c}\text { Third } \\
\text { Expert }\end{array}$ & $\begin{array}{c}\text { Forth } \\
\text { Expert }\end{array}$ \\
\hline $\begin{array}{c}\text { Completion of project } \\
\text { on time }\end{array}$ & $\begin{array}{c}\text { Ensure project runs } \\
\text { smoothly with many } \\
\text { problems }\end{array}$ & $\begin{array}{c}\text { Handle large } \\
\text { numbers of workers }\end{array}$ & $\begin{array}{c}\text { Ensure project runs } \\
\text { smoothly with many } \\
\text { problems }\end{array}$ \\
\hline $\begin{array}{c}\text { Ensure all team } \\
\text { members abide with } \\
\text { project schedule }\end{array}$ & $\begin{array}{c}\text { Manage project cash } \\
\text { flow }\end{array}$ & $\begin{array}{c}\text { Handle project in } \\
\text { hectic work area }\end{array}$ & \\
\hline $\begin{array}{c}\text { Manage team } \\
\text { members attitude and } \\
\text { work ethics }\end{array}$ & & $\begin{array}{c}\text { Manage project cash } \\
\text { flow }\end{array}$ & \\
\hline & & $\begin{array}{c}\text { Ensure no } \\
\text { construction } \\
\text { drawing error }\end{array}$ & \\
\hline
\end{tabular}

From Table 1, it can be interpreted that the common challenges according the experts in the order of similarity are ensuring the project runs smoothly within the targeted time, managing cash flow and ability to manage large number of worker. To ensure that the project runs smoothly, several factors are highlighted such as ensuring team member abide the project schedule, work with right attitude, minimise error and ability to work under hectic environment. To avoid delay, time is a crucial factor for construction operation as it will interrupt the sequencing of the construction process. Hence, any challenges must recognize and dealt early by construction leaders who play a vital role in project teams.

\subsection{Leaders' role to sustain organization's competitiveness}

Second element of the interview is to extract opinions from the experts regarding on how to ensure construction organization stays competitive which means successfully completed the project and also getting new project [8]. The first expert shared experiences in sustaining 
the organization's competitiveness by effectively utilizing resources to complete the given tasks with high productivity outputs considering cost benefit, workers, machines, and systems. Leader should adopt 'plan the work and work the plan' approach through recognizing, monitoring, and taking immediate actions and this effective approach should be applied as guide for tracking resource, schedule and time.

The second expert uses three approaches comprises of trusting subordinate's credibility in conducting work, evaluating subordinates' performances on construction progress, and aware of subordinates' responsibility to enable works be carried out as scheduled in sustaining the organization. While the third expert stressed that the importance of controlling and monitoring financial status of the project started from the early stage of project implementation. Leader should proactively follows up the work undertaken at the construction site by providing an alternative action/ plan, workaround to meet changing needs and requirements. Leader believes competitive organization must have a 'check and balance' approach among project teams to prevent one person having more power to control over the decision. The final expert sustaining the organization by ensuring accurate estimation on costing and follows the Quality Assessment System for Building Construction Work (Construction Industry Standard; CIS 7: 2006) provided by CIDB. These interview outcomes for role of construction leaders to sustain organization's competitiveness can be summarised as in Table 2.

Table 2. Summary of roles to sustain organization's competitiveness.

\begin{tabular}{|c|c|c|c|}
\hline $\begin{array}{c}\text { First } \\
\text { Expert }\end{array}$ & Second Expert & $\begin{array}{c}\text { Third } \\
\text { Expert }\end{array}$ & $\begin{array}{c}\text { Forth } \\
\text { Expert }\end{array}$ \\
\hline $\begin{array}{c}\text { Effective use of } \\
\text { resources }\end{array}$ & $\begin{array}{c}\text { Trust subordinates } \\
\text { credibility }\end{array}$ & $\begin{array}{c}\text { Control and monitor } \\
\text { project financial } \\
\text { status }\end{array}$ & $\begin{array}{c}\text { Accurate estimation } \\
\text { of construction } \\
\text { costing }\end{array}$ \\
\hline $\begin{array}{c}\text { Work according to } \\
\text { plan }\end{array}$ & $\begin{array}{c}\text { Evaluate subordinates } \\
\text { performances }\end{array}$ & $\begin{array}{c}\text { Abide Quality } \\
\text { Proactively follows } \\
\text { up work undertaken } \\
\text { for Building } \\
\text { Construction Work } \\
\text { (CIS 7: 2006) }\end{array}$ \\
\hline & $\begin{array}{c}\text { Awareness of } \\
\text { subordinates } \\
\text { responsibility }\end{array}$ & $\begin{array}{c}\text { Check and balance } \\
\text { among project teams }\end{array}$ & \\
\hline
\end{tabular}

From Table 2 shows experts' own approaches to sustain organization's competitiveness. These variety methods are useful to be shared amongst the construction parties especially the contractors to sustain their company competitiveness.

\subsection{Qualities to be an outstanding construction leader}

Regarding qualities for an outstanding construction leader, the first expert viewed that successful leaders should be innovative to break the project work into daily activities which can speed up productivity. Leader should able to foster good relationship and communication with subordinates by interacting, caring and imparting information effectively to increase cooperation and also improve project completion on-time. Likewise, leader is considered problem solver in tackling issue arises and also making a quick $\&$ right decision using resource available for smooth running of construction project. Good leader should be able to delegate work to appropriate worker based on several criteria such as qualification, experience, attitude, and competencies. Leader must act as counsellor in handling disputes at construction site and also motivator to their worker, staff and sub- 
contractor to work properly for significant impact on productivity. Construction leader needs to work with enthusiasm to make changes for productivity and placing priority to subordinates. Leader should set good examples and inspire their subordinates to emulate like them to work as a team. Leader must show great interest to work, sincere with workers, knowledgeable and hardworking. Strong leader should admit and correct the problem as a symbol of his commitment to the project teams. Outstanding leader should able to evaluate productivity of his previous works for improvement of future project. Finally, he concluded that Malaysia construction industry is vibrant which requires more leaders in the industry.

According to second expert, role of outstanding construction leader is to develop trustworthy among project teams and related parties. Strong leader committed to responsibility and monitor results continuously by evaluating performances of subordinates to achieve targeted progress. Quality leader should able to tolerance with subordinates to enhance teamwork and foster good relationship with subordinates by treating their subordinates fairly, so that, any employee mistakes able to be dealt professionally and solved immediately. Furthermore, leader should be a good problem solver and motivates subordinates to maintain their loyalty to the company. According to this expert, outstanding leaders should have good personal like honest to work and having a good time management to avoid delay.

While the third expert, views good leaders should be proactive in following up work progress and exercising empowerment in organization. Leaders need to have 'check and balance' approach among project teams to prevent one person having more power to control over the decision. Since construction organization in hierarchical structure, quality leader should able to communicate effectively, concerned, understand and listen on workers' welfare to maintaining respect from subordinates. To stay competence, leader should have do self-improvement by gaining knowledge from senior construction leaders, through reading, and actively involved in a construction project. Good leader must be a problem solver using options and resources available in addressing challenges in construction industry. Leader motivates subordinates by contingent reward to show recognition for completing the task early.

The final expert emphasized that good leader should have good communication skill by listening to subordinates to acquire updated information on construction activities. Strong quality leader should able to follow regulations, hardworking, and positive thinking. Leader should also be good problem solver in tackling any issue arises. To this expert, leaders must continually do self-improvement through reading, and actively involved in a construction project. The roles as an outstanding construction leader from all the experts' views can be summarised as in Table 3.

From Table 3, all of the experts agreed that an outstanding construction leader should possess leadership quality as a good problem solver. Besides that, three out of four experts agreed that leader should have good communication skill and also a good motivator in carrying out the construction work.

\section{Conclusion}

This study has provided valuable insight issues of leadership quality in Malaysia construction industry. It was found ten challenges and roles of construction leaders which are required to sustain organization's competitiveness. To be successful construction leaders, experts gave three most important qualities which are to act as a problem solver, able to communicate well and as a motivator to their team members. This exploratory study's outcome will be a basis for further investigation on leadership characteristics which are required by construction leaders to steer project success. 
Table 3. Summary of qualities to be an outstanding construction leader.

\begin{tabular}{|c|c|c|c|}
\hline $\begin{array}{c}\text { First } \\
\text { Expert }\end{array}$ & $\begin{array}{c}\text { Second } \\
\text { Expert }\end{array}$ & $\begin{array}{c}\text { Third } \\
\text { Expert }\end{array}$ & $\begin{array}{c}\text { Forth } \\
\text { Expert }\end{array}$ \\
\hline Innovative & Trustworthy & Proactive & $\begin{array}{c}\text { Good } \\
\text { Communication }\end{array}$ \\
\hline Good Relationship & Committed & Empowerment & Good Personal \\
\hline Good Communication & Monitor Result & Good Communication & Problem Solver \\
\hline Problem Solver & Tolerance & Competence & Committed To Work \\
\hline Decision Maker & Good Relationship & Problem Solver & \\
\hline Delegate & Problem Solver & Good Motivator & \\
\hline Good Counsellor & Good Motivator & & \\
\hline Good Motivator & Good Personal & & \\
\hline Enthusiasm & Good Time & & \\
\hline Inspire & & & \\
\hline Good Personal & & & \\
\hline Competence & & & \\
\hline Vision & & & \\
\hline
\end{tabular}

This paper was partly sponsored by MyBrain15, Ministry of Education Malaysia and the Centre for Graduate Studies, UTHM. Special thanks to all experts in construction industries for contributing and giving helpful input that made this study possible.

\section{References}

[1] C.M.M. Isa, H.M. Saman and C.N. Preece, Determining significant factors influencing Malaysian construction business performance in international markets, J. of Cons. in Devlpg Countries, 20(2), 1-23 (2015)

[2] K. Gharehbaghi and K. McManus, The construction manager as a leader, Leaders and Mgmt. in Eng., 3(1), 56-58 (2003)

[3] S.U.R. Toor and S. Ogunlana, Ineffective leadership: Investigating the negative attributes of leaders and organizational neutralizers, Eng., Cons. and Ahc. Mgmt., 16(3), 254-272 (2009)

[4] S. Nauman and A.M. Khan, Patterns of leadership for effective project management, J. Qual. and Tech. Mgmt., 20, 1-14 (2008)

[5] N.A.N. Nasaruddin and I.A. Rahman, Leadership quality for Malaysia Construction leader to steer a success construction project, MATEC Web of Conferences, EDP Sciences, 47, 1-5 (2016)

[6] X. Fei and T. H. Khan, Identifying attributes for expert construction project managers in the context of China, Intl. J. of Asian Soc. Sci., 5(7), 407-418, (2015)

[7] G. Connell, Graphic organizers for opinion writing, (2015), Retrieved on Jun 6, 2016 from http://www.scholastic.com/teachers/top-teaching/2015/03/graphic-organizersopinion-writing

[8] W. Pasmore, Developing a leadership strategy: A critical ingredient for organizational success, Greensboro, North Carolina (2014) 